\title{
Oppression, Storytelling, and Resistance in Hulu's The Handmaid's Tale
}

\author{
by Olivia Hershman, Ball State University
}

\begin{abstract}
Using the scholarship of James Berger, David Hogsettte, and other academics, this paper explores various contemporary issues seen throughout Bruce Miller's TV adaptation of Margaret Atwood's 1985 novel, The Handmaid's Tale. Investigating the Hulu series through the lens of post-apocalyptic and feminist theory, this paper examines the way that the series portrays female oppression, focuses on the power of storytelling in resistance struggles, and acts as a call for action to modern society to end the oppression of women. Examining the relevance of The Handmaid's Tale in the time of the \#TimesUP and \#MeToo Movements, the essay provides a new context in which to view women's oppression in modern society.
\end{abstract}

\section{INTRODUCTION}

Women's bodies have long been "the battlegrounds" on which and for which men fight, as Ketu Karak explains in his article, “'Stripping Women of Their Wombs': Active Witnessing of Performances of Violence” (43). As he goes on to say, women's rights, voices, and reproductive capabilities are commonly held hostage in times of social upset. This oppression of women, their bodies, and their rights proves no different in dystopian and apocalyptic representations of modern social upset and proves especially true in Bruce Miller's award-winning television adaptation of Margaret Atwood's novel, The Handmaid's Tale. The post-apocalyptic narrative follows a young woman named June as she navigates the new and strange world that has taken the place of the United States of America. Nuclear contamination and widespread infertility plague this new nation, the Republic of Gilead, which results in a fertile womb becoming the most precious commodity. All women are enslaved, and those potentially capable of reproduction become known as Handmaids and begin new lives as "two-legged wombs" (Atwood 256).

In discussing Atwood's novel, David Hogsette sums up June's new world well when he says, "Women become nonpersons-individuals who lack the rights and opportunities that might enable them to counter openly society's construction of them ... The Republic of Gilead defines Handmaids solely in terms of the condition of their ovaries, commodifying them as objectified livestock with the sole purpose of repopulating North America" (263264). While Hogsette addresses the novel, I would extend his arguments to Bruce Miller's 
TV adaptation of The Handmaid's Tale and argue that the modern adaptation gives voice to current feminist issues and dramatizes an unsettling future that most women find oddly familiar. Ultimately, Miller's adaptation of The Handmaid's Tale is both a moving and cautionary one. Yet, while it models the familiar oppression of women and the battles for their bodies, I believe that Miller uses this platform to demonstrate the post-apocalyptic role feminine storytelling has in resistance and encourages audience members to take action against the kind of oppression seen in The Handmaid's Tale.

\section{POST-APOCALYPTIC SIGNIFICANCE}

I will first be discussing the ways Miller discusses female oppression and the role storytelling has in resisting such post-apocalyptic oppression. The first tactic Miller uses to display feminine oppression and the role of storytelling in resistance is by playing with the temporal reality his characters experience. The disorienting temporal frames the characters find themselves in serve to provide them with clearly defined "befores" and "afters." They each clearly remember events before the onset of the post-apocalyptic world they now find themselves in. James Berger, in his book After the End, says,

The apocalypse as eschaton is just as importantly a vehicle for clearing away the world as it is and making possible the post-apocalyptic paradise or wasteland. Temporal sequence becomes confused. Apocalyptic writing takes us after the end, shows the signs prefiguring the end, the moment of obliteration, and the aftermath. The writer and reader must be in both places at once, imagining the postapocalyptic world and then paradoxically "remembering" the world as it was, as it is ... Every action before the apocalypse is simultaneously an action after the apocalypse, and the event itself exists as a monstrous possibility made more or less likely by actions that, if it occurs, will never happen. (6)

The befores and afters of the characters in the show become confused and often intermingle, each interacting with the other. For example, June remembers specific moments of her before; moments such as attending a feminist rally, writing a college paper on date rape, and the birth of her daughter. While she sometimes is unable to differentiate between her before and her after, ultimately, these before moments provide the lens through which June sees, and can contextualize, her after moments. Further, June's after experiences give her context to understand her experiences in the before and how they brought her to her present situation. It is because June remembers what freedom felt like, what it was to hold a job, to exercise sexual agency, or be with her family in her before that 
she establishes a lens through which she is able to find the courage for resistance in her after.

While her befores and afters may often get confused or impede upon each other, Miller ultimately uses this confused temporal sequencing to "take us after the end, show the signs prefiguring the end, the moment of obliteration, and the aftermath" (Berger 6). As Berger says, the writer, the reader, or, in our case, the audience, must also be in or understand one temporal time frame in order to understand the other, just as June does throughout the narrative. The audience must comprehend the befores of The Handmaid's Tale in order to grasp the meaning and significance of the afters that they are seeing on the screen. This temporally confused post-apocalyptic world that Miller creates in his television adaptation is one in which the past often piggybacks on the present, while the present can only be understood by remembering the past. As Berger continues, "Everything after the end, in order to gain or borrow meaning, must point back, lead back to that time; and everything before that beginning (seen as the 'beginning of the end') reconfigures itself into prologue and premonition" ( $x i$ ). Throughout The Handmaid's Tale, June must recognize her clear before and her clear after and must use one to survive and resist the other. This temporal confusion is one way Miller uses elements of post-apocalyptic literature to further exemplify feminine oppression throughout The Handmaid's Tale.

\section{MILLER'S ADAPTATION}

Now that I have discussed how Miller plays with the post-apocalyptic temporality of The Handmaid's Tale, I will touch on how Miller's adaptation differs from Atwood's original novel, as it makes room within June's story for hope and resistance, another important element of post-apocalyptic literature. While Miller does utilize the temporal confusion common in post-apocalyptic literature, his television adaptation further contrasts Margaret Atwood's 1985 novel by showcasing a post-apocalyptic world in which there is hope for oppressed peoples and a space for those oppressed peoples to resist their oppressors. While the television adaptation brings Atwood's characters to life, the space Miller creates for hope and resistance greatly differs from that within the 1985 novel. Miller elaborates on the story of June's husband, Luke, and allows audience members to follow Luke as he travels to a refugee camp in Canada and continues to search for June and their daughter. Luke's character serves to captivate much of June's memory and provides audience members a tangible link to the time before Gilead, while providing glimpses of the hope and freedom that may be possible in the after. Luke's survival and escape to Canada 
gives audience members the sometimes unrealistic hope that June and Luke may be able to return to a time resembling the before or at least create a new after for their family.

Another hope-inducing addition to Miller's adaptation is the survival and ultimate escape of June's best friend, Moira, who not only escapes her bondage as a Handmaid but also life as an enslaved prostitute at a popular club and brothel called Jezebel's. While Margaret Atwood ambiguously ends Moira's narrative at Jezebel's and includes no such happy ending, Miller again gives audience members hope that the feminine resilience and grit we see in Moira can indeed deliver an enslaved character to freedom. One of the last obvious differences between Atwood's novel and Miller's television adaptation is in the storyline of another Handmaid, Ofglen. After she is discovered as a member of the resistance group in Gilead, Ofglen faces her end. Atwood mercifully ends Ofglen's life by suicide. However, Miller is not so kind and instead uses Ofglen's story to reiterate how women's bodies become the battleground in the fight for the future and how these women bear the cost of resisting their post-apocalyptic world of domination and oppression. When Ofglen is discovered to be a member of an underground resistance group, as well as a lesbian, she is tried and convicted of being a "gender traitor." She is then forced to witness the death of her lover and undergo a clitoridectomy before being sent back to the Republic of Gilead to resume her life as a Handmaid. After everything she goes through, Ofglen comes back to the Republic and continues to push back against her oppressors and remind those around her that there is still hope. Ofglen's character is the ultimate example of grit and resilience. Ultimately, Miller gives each character an ending with far more finality, but also uses their stories to promote resilience, grit, and hope. While Atwood leaves many endings up for discussion, Miller's adaptation inspires audience members to resist the unjust and remain hopeful that the future can change for the better.

\section{CURRENT SCHOLARSHIP \& RELEVANCE}

Now that I have briefly discussed how Miller plays with temporal confusion-such as is common in post-apocalyptic writing-and how Miller's adaptation differs from Atwood's original novel, I will begin analyzing the scholarship on The Handmaid's Tale. While Atwood's novel has inspired much academic scholarship, there is no such scholarship on Miller's recent and award-winning adaptation of the novel. Thus, I will be taking the theories and comments on Atwood's novel and directly applying them to current feminist issues and Miller's modern dramatization of June's story. For example, Shirley Neuman, in her article, “Just a Backlash': Margaret Atwood, Feminism, and The Handmaid's Tale," says, 
"June, in short, is a fictional product of 1970s feminism, and she finds herself in a situation that is a fictional realization of the backlash against women's rights that gathered force during the early 1980s" (858). While I agree with Neuman that Atwood's original novel is a product of 1980's feminism and women's rights issues, I believe that the re-adaptation of June's story and the creation of Miller's television series is the timely result of modern feminism. It not only serves to reanimate Atwood's original creation but also speaks to issues that twenty-first century women are currently confronting, such as social and sexual oppression. Miller's adaptation also explores the role storytelling has in resisting such social and sexual oppression, just as storytelling has become an important part in resisting social and sexual oppression in modern feminist movements.

These modern movements have been gaining speed throughout the United States, such as the \#MeToo and \#TimesUP Movements. The frontrunners of the \#MeToo Movement and those involved with the campaign to raise awareness and encourage solidarity against sexual violence and harassment were recently featured as TIME Magazine's Persons of the Year. Millions of tweets and hashtags showed up just hours after the campaign's worldwide relaunch. The movement included people from every demographic. Since then, the \#TimesUP movement has swept through Hollywood, and hundreds have come forward with their narratives of sexual assault, harassment, and inequality in the workplace. For the men and women involved in these situations, there is a clear before and a clear after in which things will never be the same. Just as Berger says regarding apocalyptic and post-apocalyptic events, "Everything after the end, in order to gain or borrow meaning, must point back, lead back to that time; and everything before that beginning (seen as the 'beginning of the end') reconfigures itself into prologue and premonition" $(x i)$. These survivors of sexual oppression have faced their own apocalypses yet seemingly have found support and the courage to resist by telling their stories. Much like the characters of The Handmaid's Tale, they must also use their befores to help create their afters. However, if we look at such media as Miller's The Handmaid's Tale, in which there is also a clear before and after, we understand that even though there may be a clear divide from which there is no going back, there is also room for hope, a chance to fight back, and a way to recreate an after. It is clear from even these few contemporary examples that Miller's The Handmaid's Tale speaks to current issues and provides audience members with the reassurance that, even though an apocalyptic event has occurred, there is still hope and room for resistance, as I will discuss later.

In addition to writings by James Berger regarding post-apocalyptic literature and the 
genre's temporal confusion and ambiguity, I will be referencing work by such scholars as Elisabeth Hansot, David Hogsette, and Karen Magro. I will ultimately discuss how Bruce Miller's adaptation of The Handmaid's Tale not only exemplifies the familiar oppression of women but also how it explores the role of post-apocalyptic storytelling in resistance and how it remains a powerful call for modern social reform.

\section{OPPRESSION}

While I have briefly touched on how Miller adopts pieces of apocalyptic theory, such as Berger's, to show oppression in The Handmaid's Tale, I will be taking a closer look at exactly how this feminine oppression is exemplified in the show. Like many postapocalyptic work that seeks to draw a strong emotional response from audience members, The Handmaid's Tale depicts very intense and disconcerting oppression. While this oppression is startling, upon further examination, it is not too different from what modern women are familiar with and experience on a daily basis. To repeat a quote from Hogsette: "Women become nonpersons-individuals who lack the rights and opportunities that might enable them to counter openly society's construction of them" (263). While this illustration of women may seem exclusive to the confines of Atwood's novel and Miller's adaptation, I would argue that this view of female oppression is also applicable to modern women. The fact that women are portrayed as such "nonpersons" in the narrative as well as in our current society is what, I believe, makes Miller's adaptation so relevant to today's society, as I will discuss later.

In Miller's adaptation, no woman is excused from the oppression enacted by the Republic of Gilead. Even the elite women of society and infertile wives of influential government officials are barred from reading, writing, or speaking out of turn. This is exactly, as Shirley Neuman describes, the ideal "post-feminism" woman of the 1980s: "[they should be] submissive and more abnegating than any wife this side of the Orient" (860). This is precisely how the women in Miller's Gilead are seen. Again, these parallels are what make Miller's adaptation so relevant. All women of Gilead are commodified based on the reproductive capabilities of their wombs. However, the Handmaids of Gilead are treated as slaves; they have absolutely no rights, no voice, and no freedoms. They are physically abused, sexually assaulted, and mentally manipulated. They are stripped of everything that previously defined them as human, separated from their innate "personhood," and "render[ed] non-human," all of which succeeds to make these incredible acts of oppression possible (Katrak 41). 
In exploring how apocalypse intersects with this female oppression, I will be using James Berger's definition of apocalypse as events that function as "definitive historical divides, as ruptures, pivots, fulcrums separating what comes before from what comes after ... All preceding history seems to lead up to and set the stage for such events, and all that follows emerges out of that central cataclysm" (5). According to this definition, the dystopian world presented in The Handmaid's Tale most definitely qualifies as an apocalypse, especially for any female character. Miller presents a clear before and a clear after in which June finds herself, which acts as a historical divide between the then and the now. Again, we see Miller playing with June and the audience's sense of post-apocalyptic temporal reality. Everything that came in the before allowed for the Republic of Gilead to emerge in the after. Both June and the audience must understand one to create a frame for the other.

For example, in the before, June was a book editor and was free to practice her literacy at any time. However, literacy and free thought were some of the first things to disappear in the after. Women are banned from and severely punished for reading in Gilead. Yet, June encounters several instances of literacy in the after: playing Scrabble with the Commander and reading the message scratched into her closet. In order to understand why June is so fascinated with and encouraged by these chances at literacy and reading, the audience must understand her before and the very literate world June experienced in the before. In order to understand the magnitude of the freedoms June experienced in the before, we must understand the oppression she, and every other woman of Gilead, is currently experiencing in the after. This is just one example of how Berger's theory of the before, after, and a dividing apocalyptic event play a role in The Handmaid's Tale and in June's narrative account.

\section{STORYTELLING}

Complementing June's interaction with literacy throughout her after, we see her exercising the storytelling skills she possesses by, quite obviously, telling her story to audience members. Despite the horrendous oppression and suffocating slavery she experiences, June finds a way to tell her story, and through her rebellious narrative acts, she retains her identity and her sense of hope. Identity and use of language are closely linked throughout June's tale. Handmaids are not allowed to read, write, or speak out of turn. They are given new names that signify their "masters" and to whom they belong. This lack of literacy and restricted speech keeps them within the realm of Gilead-acceptable identities 
and does not give them the power to recreate their own identities. Regarding Atwood's novel, David Hogsette says, "[The Handmaid's Tale] examines the political, social, and sexual dimensions of discourse, focusing specifically on oppression enforced by institutionalized control of acquiring knowledge and using language and on the self-liberating potential of an individual's act of storytelling” (263). Applying this scholarship to Miller's television adaptation, we clearly see the control of literacy and language, as discussed previously. Throughout the show, we see June navigate the political, social, and sexual "dimensions of discourse," yet she lacks the language to participate fully and establish her identity as a participant in such discourse (Hogsette 263). By restricting the language use of women, Gilead ultimately silences and excludes them from almost all social dialogue.

This repression of language serves only to make the language and storytelling that is available even more powerful because it is so controlled. In Episode Four, June finds the words "Nolite Te Bastardes Carborundorum" carved into her closet wall. "Don't let the bastards grind you down" has since become a war cry for many feminist issues and a running theme of June's story. She says, "There was an Offred before me. She helped me find my way out. She is dead. She is alive. She is me. We are Handmaids. Nolite Te Bastardes Carborundorum, bitches" ("Nolite Te Bastardes Carborundorum”). This act of storytelling by a former Offred simultaneously establishes her own identity and passes along the message that she existed, that she believed in the person who would come after her, and that she ultimately believed in the hope that her written resistance provides.

Like the woman who left the message in the closet, June and the other Handmaids find ways to tell their stories as well and, ultimately, find ways to retain or recreate their identities through their storytelling abilities. While it is obvious that June is eventually able to use her voice and tell her story, her act of storytelling throughout her experience serves to both remind June of her former identity and to help her create a new one. The act of storytelling is what I believe gives June the strength to resist. Throughout her experiences, she frequently flashes back to her past and tells herself, and her audiences, stories from her life before. We travel with her into memories from her past: the day her daughter was born, times with her best friend Moira, and conversations she had with her husband Luke. As Elisabeth Hansot says regarding the novel, "[These stories] reestablish some continuity with her discredited past and give amplitude to her impoverished present" (57). June's act of storytelling gives her a way to not only connect herself with her before, but provides a way for June to use her before to understand and resist her present self and the post-apocalyptic after in which she finds herself. 
These memories are what help June revisit her previous identity as a wife, a mother, a friend, and a free person. They help her to form a new identity in the strange context of her present situation. Her memories and stories are how she remembers a time before and a time when things were different. They, along with her act of storytelling, are what bring her back to the realization that life can and should be different and that she does have the power to fight back. Addressing June's capacity to fight back against her oppression, scholar David Hogsette says,

[The Handmaid's Tale] demonstrates through June that women, able to take risks and tell their stories, may transcend their conditioning, establish their identity, joyfully reclaim their bodies, find their voices, and reconstruct social order . . . language use is both politically oppressive and, ultimately for June, self-liberating ... Writing, or in her case speaking out, validates an individual's existence; it proves that writerspeaker was, at some point, or still may be, alive ... Someone was present to write it . . by creating her own text, her own narrative, June similarly creates and validates her existence, her humanity, and her vision of reality and preserves her experience for future audiences ... $(264,269)$

While this theory was written in regards to Atwood's novel, it is easily applicable to the television show, as well as to modern instances of oppression in which women used their linguistic and storytelling abilities to resist their oppressors.

Gilead thinks that by restricting women's uses of language and literature, it will be able to suppress their voices and their identities as well. However, it only strengthens the power of their stories and the power of the limited words they have access to. It also proves that they have hope in not only an audience to listen to their stories but also in a future in which such an audience would be free to hear their stories.

\section{ACTION}

June's narrative thus acts to both startle audience members and move them to recognize the similarities between Gilead and our current social climate. When Atwood originally penned June's story, it was seen as "a fictional product of 1970s feminism, [where June] finds herself in a situation that is a fictional realization of the backlash against women's rights that gathered force in the early 1980s" (Neuman 858). While I agree that this may have been the case of Atwood's novel, I would add that Miller's recent adaptation of The Handmaid's Tale is a product of twenty-first century feminism and ultimately serves as a cautionary tale and as a call to action for our current society. The show clearly depicts 
many of the issues that second-wave feminists faced, yet the issues presented are all eerily familiar to women of the twenty-first century. It makes audience members wonder if any positive strides have been taken in women's rights in the past forty years. Shirley Neuman expands on what The Handmaid's Tale shows us about this time before, the time members of the Republic of Gilead use to condone their behavior. I believe that the things she mentions are the very issues that Miller's adaptation also strives to address. She says,

[the time before] also tells us that it was not safe for a woman to go for a run or into a laundromat at night, to open a door to a stranger, to help a stranded motorist; that women didn't walk in certain places, locked doors and windows, drew curtains, left lights on as precautions or perhaps "prayers"; that women needed to "take back the night" and to replace kitchen table abortions with legal freedom of choice; that date rape was common enough to be an accepted subject for a term paper; that pornography ... was a fact of life; that women were "found" ... in ditches or forests or refrigerators in abandoned rented rooms ...; that one did not allow one's children to walk alone to school because too many disappeared; that less terminally lethal circumstances included singles bars, blind dates, the terrible gap between the ones who could get a man easily and the ones who couldn't as well as a dedication to anorexia, silicone implants, and cosmetic surgery as a means to realize "possibilities" proffered by fashion magazines; that fathers left without paying child support, mothers wound up on welfare, and the wretched little paychecks of women would have to stretch to unsubsidized daycare ... (Neuman 866)

It is clear that these things are widely seen in both our current society and the time before Gilead. This causes me to wonder if our society, left unchecked, could, or maybe has, turned into a narrative like The Handmaid's Tale. LGBTQ and women's rights, poverty, literacy, sexual slavery, war, toxic pollution, political conflict, "sexual politics, a woman's decision to bear children, her access to power, and her ability to determine her own destiny" are all still issues at the forefront of our current political climate as Karen Magro discusses in her article, "Gender Matters: Revisiting Margaret Atwood's The Handmaid's Tale and The Penelopiad through the Lens of Social Justice" (20). Miller utilizes and manipulates Atwood's original story to draw attention to these issues, which we still need to address and solve or otherwise risk our world completely turning into one like the Republic of Gilead.

Perhaps the most frightening part of The Handmaid's Tale is that these eerily familiar changes didn't happen all at once. As June says, "When they slaughtered Congress, we didn't wake up. When they blamed terrorists and suspended the Constitution, we didn't 
wake up then either ... They said it would be temporary. Nothing changes instantaneously. In a gradually heating bathtub, you'd be boiled to death before you knew it" ("Late"). And, like a gradually heating bathtub, the United States depicted in the show only makes small changes at first. This should make us, as an audience and as committed members of society, jump up and call out these injustices that we see. In the beginning of Gilead, women slowly lose their rights, their jobs, their money, and their independence, and people don't say much about it. America's democracy is gradually taken over by a militaristic Christian government and almost all personal freedoms are eradicated. While this totalitarian way of life greatly contrasts with the democracy that Americans formerly prided themselves on, like June says, things changed slowly, but eventually things changed completely. Furthermore, we are currently seeing issues of women's rights and oppression in our current world, such as those that inspired the \#MeToo and \#TimesUP Movements. While there are so many uncanny similarities between our world and Gilead, The Handmaid's Tale shows us that there is a way to resist and that not only recognizing this oppression but sharing personal narratives of oppression is a large step in the direction of resistance and justice.

By showing this violence against women and this incredibly unjust society, Miller succeeds in "involve[ing] and affect[ing] audiences as active witnesses" and works to trigger a sense of social justice that "they take outside the theatre" (Katrak 31-32). Miller's adaptation of Margaret Atwood's The Handmaid's Tale should not only serve to dramatize oppression against women, but it demonstrates the role storytelling has in fighting and surviving such oppression. Ultimately, it should motivate audience members to notice and take action against the oppression and human rights issues that we easily see in our own world.

\section{WORKS CITED}

Atwood, Margaret. The Handmaid's Tale. Houghton Mifflin Harcourt, 1985.

Berger, James. After the End: Representations of Post-Apocalypse. University of Minnesota Press, 1999.

Hansot, Elisabeth. "Selves, Survival, and Resistance in The Handmaid's Tale." Utopian Studies: Journal of the Society for Utopian Studies, vol. 5, no. 2, 1994, pp. 56-69. EBSCOhost, http://www.jstor.org/stable/20719313. 
Hogsette, David S. "Margaret Atwood's Rhetorical Epilogue In The Handmaid's Tale: The Reader's Role in Empowering June's Speech Act.” Critique: Studies in Contemporary Fiction, vol. 38, no. 4, 1997, pp. 262-278. EBSCOhost, doi:10.1080/00111619.1997.105431 80 .

Katrak, Ketu H. “'Stripping Women of Their Wombs': Active Witnessing of Performances of Violence.” Theatre Research International, vol. 39, no. 1, Oct. 2014, pp. 31-46. EBSCOhost, doi:10.1017/s0307883313000539.

“Late.” The Handmaid's Tale, season 1, episode 3, Hulu, 29 Apr. 2010. Netflix, www.hulu.com. Magro, Karen. “Gender Matters: Revisiting Margaret Atwood's The Handmaid's Tale and The Penelopiad Through the Lens of Social Justice.” Notes on American Literature, vol. 22, 2013, pp. 20-28. EBSCOhost, proxy.bsu.edu/login?url=http://search.ebscohost.com/log in.aspx?direct=true\&db=lkh\&AN=90667091\&site=ehost-live\&scope=site.

Miller, Bruce, creator. The Handmaid's Tale. Daniel Wilson Productions Inc., 2017.

Neuman, Shirley. “Just a Backlash': Margaret Atwood, Feminism, and The Handmaid's Tale." University of Toronto Quarterly, vol. 75, no. 3, 2006, pp. 857-868. EBSCOhost, doi:10.3138/utq.75.3.857.

“Nolite Te Bastardes Carborundom.” The Handmaid's Tale, season 1, episode 4, Hulu, 29 Apr. 2010. Netflix, www.hulu.com. 